ПОЛІТИЧНІ ПРОБЛЕМИ МІЖНАРОДНИХ ВІДНОСИН

УДК 321: 620.94

\title{
EGYPT UNDER THE RULE OF ABDEL FATTAH EL-SISI: INTERNAL CHALLENGES
}

\author{
СГИПЕТ ПІД ВЛАДОЮ АБДЕЛЯ ФАТТАХА АЛЬ-СІСІ: \\ ВНУТРІШНІ ВИКЛИКИ ДЛЯ РОЗВИТКУ
}

\section{ЕГИПЕТ ВРЕМЕН ПРАВЛЕНИЯ АБДЕЛЯ ФАТТАХА АЛЬ-СИСИ: ВНУТРЕННИЕ ВЫЗОВЫ ДЛЯ РАЗВИТИЯ}

Ignatiev P. M.

Doctor of Political Science, Professor of the Department of Country Studies of the Institute of International Relations of Taras Shevchenko National University of Kyiv. E-mail: pavloi@yahoo.com

\section{Ігнатьсв П. М.}

Доктор політичних наук, професор кафедри країнознавства Інституту міжнародних відносин Київського національного університету імені Тараса Шевченка. E-mail: pavloi@yahoo.com

\section{Игнатьев П. Н.}

Доктор политических наук, профессор кафедры страноведения Института международных отношений Киевского национального университета имени Тараса Шевченко. E-mail: pavloi@yahoo.com

Abstract. Egypt is the demographic giant of the world with strategic location at the crossroads between different continents. The country was under rule of military generals since 1952 and the first competitive presidential elections in its history took place only in 2012. The latest period of military rule under the President Hosni Mubarak lasted from 1981 till 2011. It was a time of a relative stability and the lack of crucial reforms when Egypt was supported by generous US aid and tourism expenditures. Is this about to change after the "Arab Spring» and short term of Mohammed Morsi s presidency? Such issues as demographic explosion and high levels of unemployment, forced military conscription, the lack of affordable housing and scarcity of water resources are examined. The author makes an attempt to analyze how Egypt is trying to cope with those challenges under the rule of Abdel Fattah el-Sisi. To this end he looks into the development of different spheres of economic activity like tourism, the transit via Suez Canal, remittances and cotton agriculture.

Key words: Egypt, population explosion, military rule, river resources, Suez Canal, tourism.

Анотація. Сгипет вважається демографічним велетнем світу і відзначається важливим стратегічним розташуванням на перетині різних континентів. Країна перебуває під владою військових генералів з 1952 р., а перші відкриті та прозорі президентські вибори відбулися тут тільки в 2012 р. Останній період військового правління на чолі з Хосні Мубараком тривав із 1981 по 2011 рр. Цей був час відносної стабільності та відсутності радикальних реформ, коли Сгипет виживав за рахунок значної допомоги з боку США 
і коштів, які залишали у країні іноземні туристи. У статті запропоновано відповідь на питання, чи змінилася ия ситуація після подій «Арабської весни» і нетривалого правління Мухаммеда Мурсі. Проаналізовані такі проблеми як демографічний вибух і пов'язаний із ним значний рівень безробіття, примусова військова служба, відсутність доступного житла, гострий дефічит водних ресурсів. Автор намагається встановити, яким чином Єгипет протистоїть циим викликам у роки правління Абделя Фаттаха аль-Сісі. Задля цього він досліджує, як при новому главі держави розвиваються такі сфери економічної активності як туризм, обслуговування транзиту суден Суецьким каналом та забезпечення населення грошовими переказами, а також оцінює ефективність роботи бавовняної галузі сільського господарства.

Ключові слова: Сгипет, демографічний вибух, військове правління, річкові ресурси, Суецький канал, туризм.

Аннотация. Египет считается демографическим гигантом и характеризуется стратегически важным положением между двумя континентами. С 1952 г. страна пребывает под властью военных, а первые открытые и свободные выборы были организованы здесь в 2012 г. Последний период военного властвования при Хосни Мубараке продолжался с 1981 по 2011 годы. Это было время относительной стабильности и отсутствия радикальных реформ, когда Египет выжсивал за счет существенных объемов помощчи из США и средств, которые поступали от иностранных туристов. В статье предложен ответ на вопрос, изменилась ли эта ситуация после событий «Арабской весныl» и непродолжсительного правления Мухаммеда Мурси. Проанализированы такие проблемы как демографический взрыв и связанный с ним уровень безработицы, обязательная воинская служба, отсутствие доступного жилья, острый дефицит водных ресурсов. Автор пытается установить, каким образом Египет справляется с подобными вызовами во время правления Абделя Фаттаха аль-Сиси. В связи с этим он изучает, как при новом президенте развиваются такие сферы экономики как туризм, обслуживание транзита суден Суэиким каналом и содействие населению в получении денежных переводов, а также анализирует эффективность работы хлопкового хозяйства.

Ключевые слова: Египет, демографический взрыв, власть военных, речные ресурсы, Суэикий канал, туризм.

The current problem. Egypt is the most important player in the Middle East and Northern Africa if to consider her strategic land area and demographic resources. However, the country became a hostage of failed demographic policy, restrictive economic regime and omnipresence of military in public life. Even the events of the violent «Arab Spring» did not change this situation. The research assumption of the author is that overpopulated and water-scarce Egypt, whose ruling elite has also created a vicious circle of subsidies and overwhelming reliance mainly on state employment, can not develop herself without the profound liberalization of economy and the program of population control. The aim of the article - is to explore the peculiarities of internal challenges to Egypt in the wake of the fall from the power of "Muslim Brotherhood" and to analyze the most pressing problems of that country, which are tightly connected to demographic explosion and economic mismanagement. Main research steps include defining the reasons behind the demographic explosion, consequences of its influence on Egyptian economy and formulation of recommendations for necessary reforms.

Analysis of the latest publications. The sources of information, used in this article, are taken from regional mass-media outlets Al-Ahram Weekly, Egypt Independent, Middle East Eye, The Daily News Egypt, The National, The Times of Israel. Among Ukrainian authors P. Bov- 
sunivskiy claims that Mohammed Morsi's attempts to get as much power as possible along with the swift contraction of forex reserves set general public against him and made military circles popular again [1, c. 38-41]. Several Russian authors A. Vasiliev, A. Korotaev and L. Isaev believe that the events of 2011 forced many tourists to leave Egypt and Islamists could not operate efficiently without monetary support of the Gulf monarchies [2, c. 2-7]. In his another scientific work L. Isaev links the return of the military rule to the unwillingness of Egyptians to participate in new protests, the support of Sisi by business circles and the assumption of population that political Islam has failed [3]. So, it is necessary to say that the comprehensive analysis of Egypt's challenges under the rule of Sisi was not contemplated by any of aforementioned researchers.

Egypt with more than 92 million residents is the holder of different population records. This is the largest Arab country in the world and the third largest country in Africa demographically only behind Nigeria and Ethiopia. But if to add 8 millions of Egyptians abroad, Egypt would be on a par with Ethiopia [4]. The majority of population resides on the shores of the Nile - the longest river in the world, which has a length of 6650 kilometers. Capital Cairo (this name can be translated as "Victorious") is the prominent African megacity with 12 million residents and 20 million occupants in the Greater Cairo zone [5]. Only Peruvian Lima and Egyptian Cairo are the two major urbanized centers situated within a vast desert area with limited water resources.

Egypt is the most prominent example of population explosion in Africa. The birth rate in the country constitutes 3,5 children per woman and each year the population increases by 2 million people [6]. This is because Egyptians predominantly live in rural areas where opportunities for jobs and education are limited but working hands always in great demand. Moreover, the abortions here are outlawed except the cases of threat to the health of a mother. The people in the countryside are also religious and believe that the state does not have a right to regulate sexual activity of parents because only God decides who and when should be born [7]. The proof of religiosity can be seen on the foreheads of ordinary Egyptians that are badly bruised because of five prayers during the day.

$22 \%$ of citizens of Egypt occupy the region around the Greater Cairo, and the majority of the rest - the belt of fertile land along the Nile. The Nile Delta encompasses 25 thousand square kilometres and houses almost half of the population [8]. This is a principal source of Egyptian food. The water of the river also allows for year-round fishing. The most famous local predator is a Nile perch, which can grow up to two meters and whose meat is widely consumed by locals. However, the river's biomass is under the risk of vanishing under the influence of population explosion. Overpopulation near the Mediterranean coast also forced local fishermen to search for a catch in the waters of another Northern African states and to deal with a profitable smuggling of refugees to Europe.

Because of pressure on land and lack of jobs around 27,8\% of Egyptians are living in a dire poverty. By local classification the poor are those people that are getting less than 428 Egyptian pounds per month since 1 US dollar equals 18,5 pounds in 2017 . Higher levels of this phenomenon are typical for the rural areas of Upper Egypt where poverty exceeded 56\%, while the level of it in Lower Egypt did not grow over 19,7\% [9]. Unemployment rate constitutes 12\% despite the pledge of the President Abdel Fattah el-Sisi to reduce the number of jobless people to $10 \%$ [10]. The floating of the pound and inflation in 2016 will cause more poverty and also mean more unemployment. To make matters worse, slow economic growth can not catch up with demographic explosion, which causes the hike in purchases of the foodstuff.

The military-dominated state is not in a position to liberalize economy, but have to employ young Egyptians that en masse enter workforce market on annual basis. As a result, at least 6 
million people are working in a bloated and ineffective public sector. All rulers of Egypt tried to redistribute the wealth in order to calm down their growing population. Several years ago Egyptian Civil service constituted a whopping $25 \%$ of the whole workforce and each state employee served 13 ordinary Egyptians - a proportion not seen in anywhere in the world. Annually those people, who largely do little work and are not highly qualified, receive an increment to their wages because of a rising inflation and the process of hiring them continues to be driven by family connections [11].

Moreover, what is highly unusual, military enterprises account for a considerable share of GDP and own hotels, recreational clubs, construction companies, and factories producing popular consumer goods. This can be considered a legacy of military rule since 1952, when all tenders went to affiliated with generals entities or to private players connected to army in any way, thus killing the competition and providing inferior services to general population. The last major war for Egypt ended in 1977 and afterwards the numerous armed forces had to find another occupation. After the peace treaty with Israel in 1979 defence budget was diminished due to introduction of American military assistance and generals decided to get a new source of enrichment in a civil economy. Today this system encompasses almost all spheres of economic activity. Military retirees work as consultants or directors of state enterprises and they also supervise a production of a wide range of consumer goods. Generals sell or let to big businesses expensive land plots in coastal recreational zones or in areas of priority development near the Suez Canal. At least $45 \%$ of economy is controlled by the armed forces that routinely use the free workforce of 500,000 conscripts and a cheap subsidized fuel provided by the state for the purposes of national defence [12].

All males aged 18-30 years have to serve in armed forces and by doing so they create a huge labour pool, whose representatives are completely unable to protect their rights. Only soldiers in the Sinai Peninsula are relieved of such duties because of the counter-insurgency operations against Islamic State, which they perform by manning the numerous roadblocks. However, the President Abdel Fattah el-Sisi claims without any justification that military enterprises contribute only 2\% to Egypt's economic output [13]. On the other hand, their owners back up the state and increase popularity of the regime among the population with generous loans and handouts of different socially-oriented goods like milk powder, frozen meat or flour to urban poor.

Safa Joudeh claims that the long rule of the President Gamal Abdel Nasser created a precondition for a military control over economy, because trusted generals were tasked with the supervision of the most important national projects. Today army contributes to the problems of private sector with unfair competition. Military enterprises don't pay taxes, enjoy an access to cheap state resources and subsidized labour force. The ruling class does not allow the supervision of the activities of those companies by society under the pretext of the matters of national security [14].

Egypt also has an acute water problem, which threat about to grow in correlation with population explosion. The ancient civilization in the country was born on the shores of the Nile and farmers waited for the annual flooding of that mighty river that brought silt to their lots as a natural fertilizer. But Egypt is a low riparian state and depends on all other countries of the Nile basin in question of water distribution. The opening of the Aswan High Dam in 1970 put to the end the flooding of the Nile and allowed to store flood water in a huge 550-kilometers long artificial Lake Nasser - one of the largest man-made lakes in the world between Southern Egypt and Northern Sudan. However, the liquid in this storage facility with a depth of 180 meters is prone to heavy evaporation under constant desert sun in extremely arid climate. The water also disappears from canals emanating from Nasser Lake, since they are open to the sun and have 
cracks in the walls. Finally, the layers of silt constantly grow in the lake instead of fertilizing the fields of the farmers. Egypt is annually consuming a whopping 60 billion cubic meters of water with a deficit constituting more than 30 billion, since each Egyptian citizen needs at least 1000 cubic meters in order to meet the most basic needs [15].

Randa el Bedawy claims that Egypt is simultaneously facing the scarcity of fresh water and the growing threat of salt water from the Mediterranean Sea as a result of construction of Aswan High Dam and the harmful effect of global warming. Despite the fact that country uses a lion's share of the Nile resources in process of irrigation, it still satisfies $50 \%$ of demands in grains via import. The author points out that the rulers of Egypt should limit demographic explosion, protect water from pollution and establish friendly relations with other states of the Nile basin for the sake of joint projects of water-sharing [16].

Only $6 \%$ of Egyptian land area of 1 million square kilometres is arable and the Blue Nile remains a principal source of the water. Moreover, the country suffers because of low annual rainfall of $51 \mathrm{~mm}$. Under those circumstances the decision of Ethiopia to go ahead with construction of the «Great Renaissance Dam» («GERD») in 2010, poses a serious danger for Egypt. Upon its completion the mega object is designed to generate 6000 megawatt of energy and to store more than 70 billion cubic meters of water, which also might be prone to evaporation [17]. "GERD", as continent's largest hydropower plant in the nearest future, will allow Ethiopia to export the current to neighbouring countries of Eastern Africa like Kenya and Tanzania at Egypt's expense. In the long run this mountainous «Diplomatic Hub of Africa» is striving to become continent's largest exporter of current. Moreover, only a quarter of Ethiopians have an access to electricity and because of this the transmission lines are not developed [18].

Since 2009 the Nile Delta has faced the threat of loss of drinkable water because of the rising levels of saline currents from the Middeteranian Sea. But the problem of «GERD» may aggravate this phenomenon even further by helping the seawater to prevail over the Nile. Official Cairo under the President Hosni Mubarak largely ignored African affairs and today pays a heavy price, since the countries of the Nile basin are indifferent to Egyptian position in anticipation of cheap Ethiopian electricity. The «Arab Spring» in Egypt and subsequent turmoil after the military coup in 2013 along with break-up of old Egyptian ally Sudan into two countries allowed Ethiopian regime to complete a lion's share of work over GERD without fuss. Moreover, some rulers of other 10 Nile riparian state actors are considering a generous use of water by Egypt as unresolved colonial question, forced upon them by the British Empire on Egyptian behalf in 1929.

Tobias von Lossow and Stephan Roll claim that for Ethiopian leadership «GERD» is important national project, which is entirely funded by the country. Egypt is too far away to wage a war against Ethiopia effectively and lacks allies for such a campaign since official AddisAbaba is a vital partner of the USA in anti-terror campaign in Eastern Africa and strategic asset for the Gulf states because of their considerable investments in Ethiopian fertile land with abundant rainfall [19]. One should add that Ethiopia is considered a diplomatic capital of Africa and the most important partner of the UNO in the region as a host of numerous refugees.

Egypt is the fifteenth among the most densely populated countries in the world, what puts a heavy toll on water resources. But this is not the only problem, since she is notorious for illegal settlements, where people clandestinely gain an access to water supply pipes in the cities. The Nile water is also used to cool down the equipments of plants, which discharge industrial waste directly into the river. The population of the banks contributes to rising levels of pollution with garbage because of its huge numbers and low ecological awareness. Moreover, the construction of Aswan High Dam led to the proliferation of a river plant - giant water hyacinth, which gen- 
erously consumes water and quickly increases the size of swamp areas. Before 1970 the fast current of the Nile uprooted hyacinths and carried them to the Mediterranean Sea but today they are safe and continue to spread at alarming rate. This weed is recognized among the top 10 most aggressive in the world because of the speed of growth and exceptional environmental tolerance. For example, one flower can release 3000 seads annually [20].

The scarcity of water and arid sandy nature of a landscape directly influences the stability of Egypt. Today the population puts a heavy toll on overstretched economy. Since January 1977 bread riots with massive death toll under the rule of the President Anwar Sadat, the authorities did not dare to abrogate generous food subsidies. As a result of continuity of state policy, a whopping 68 million of the total 92 million people receive subsidized food. This situation deteriorates further if to take into account that country is self-sufficient only in rice, potatoes, tomatoes, onions and citrus fruits, but rice cultivation is water-extensive and local farmers are forced to reduce areas under rice plants in order to save a precious water. All other types of foodstuff have to be imported. Egypt satisfies with purchases abroad 32\% of sugar, $60 \%$ of corn, $70 \%$ of wheat and beans and $97 \%$ of its cooking oil requirements [21].

Moreover, this country has the largest aquaculture industry in Africa as the second largest producer of tilapia in artificial water reservoirs only after China. In 2015 Egyptian aquaculture provided population with some 1,56 million metric tons of fish satisfying almost $79 \%$ of the requirements in meat consumption. Therefore local companies working in this field of economic activity are forced to import feed grain and soybean meal from abroad at a large scale [22].

At the same time Egypt is world's top importer of wheat with 11 million tonnes of annual purchases and thus remains sensitive to the hikes of world prices on this commodity. The favourite food of the poor koshary and traditional flat street bread aish of pita type grow in price on a daily basis. Koshary is a vegetarian dish of rice, noodles and lentils together with a tomato sauce with fried onions and usually sold from street carts to majority of blue-collar workers during the midday break. Since Egypt is only self-sufficient in rice production, all other ingredients of it have to be imported in times of a rising American dollar [23]. The same problem concerns also black tea - the national drink of Egypt, which local residents typically sweeten with huge loads of sugar and consume many times during day.

The dependence on the countrywide net of subsidies along with huge import needs create numerous opportunities for corruption. Many state servants, responsible for distribution of cheap food supplies, are corrupt, since they are withholding essential goods and resell them at black market. Moreover, the lack of accountability of military enterprises adds to the problem. In 2016 the ranking of «Transparency International» defined the position of Egypt as $108^{\text {th }}$ out 176 countries [24].

Egyptians are forced to buy the cheapest goods available instead of healthy food and are also reliant on street vendors that sell koshary, falafels, sugary tea, and as a result - are increasingly becoming the victims of obesity. For example, $85 \%$ of Egyptian women are suffering from excessive weight and $48 \%$ are seriously obese because they are unable to afford a food of good quality and usually give birth to many children, consuming a huge number of calories in process of pregnancy [25]. This causes a surge in numbers of heart deceases and contributes to diabetes epidemic leading simultaneously to constant demand of expensive Western medicines.

Moreover, the population explosion puts a heavy strain on a housing infrastructure. The country lacks 3 millions of houses in order to resolve the current problem, but developers construct only 20 thousand units on a yearly basis [26]. The remittances are playing increasingly important role in the growth of this industry during the periods of Egyptian pound devaluation, since prices are quoted in local pounds, but the majority of Egyptians are too poor to buy houses 
in major cities and need to join programs of construction of low-cost panel houses made from the cheapest materials available and built in suburbs on a desert land. Not everyone agrees to leave cities, where jobs in informal economy are widespread. There are considerable pockets of illegal settlements in Cairo and Alexandria with the most infamous place in the Middle East known as «Necropolis» is situated in a capital of Egypt. In that area more than 500 thousand people found their new home within the old cemetery. The explosive growth of population also forces Egypt, one of Africa's top energy producers, to import more crude oil and gas, because local energy resources can not make up for it. Country's economy not diversified enough to produce a wide selection of consumer goods, what created preconditions for the development of a huge trade deficit.

One must say that Egypt needs a strict program of population control, probably the introduction of measures of gradual redistribution of food subsidies and cheap drugs towards small families and heavy fines against parents with many children. The state should also advertise the advantages of families with one or two children, provide population with means of protection and introduce lessons about population control in schools.

Egypt is unable to meet the challenge of population explosion without developed economy. This North African country has relatively few sources of income despite the fact that it represents continent's third largest economy after Nigeria and South African Republic. First of all, the «Land of Pharaohs» gets considerable amounts of hard currency from the industry of hospitality. Egypt, Morocco and South Africa are three most popular countries in Africa for international tourists [27]. The main reasons for this are following. First, Egypt is situated close to Southern Europe and can be considered a cheap winter holiday resort for Europeans with famous recreational places like Hurgada, Sharm-el-Sheikh and Dahab, despite its cold nights and periodic sand storms from the Sahara desert. Second, The Red Sea is suitable for swimming during the whole year as well as for scuba diving in a search for corals. By the number of pyramids Egypt is the second in the world only after neighboring Northern Sudan but those structures in Cairo's Giza district along with a nearby Sphinx are the most famous. Sacred places of Jordan or Israel are not far away and can be reached via a daily excursion from the resorts in the Sinai Peninsula. Finally, The Nile, world's longest river, is popular destination for cruise ships and tourists also can rent a local wooden boat felucca with triangular sails or to fish for giant Nile perch from a modern yacht. The trip on a board of the ship allows to see Southern Egypt with famous temples of Abu-Simbel, Karnak and Luxor as well as a Aswan High Dam during one week, 10 or 17 days. Hotel capacity in Egypt exceeds 210 thousand rooms and another 120 thousand rooms are being constructed [28].

Tourism industry represents one of the main drivers of economy, however, the number of notorious developments put it to the test. Only in 2010 close to 15 million tourists paid a visit, but subsequent events of the "Arab Spring» and military coup made Egypt the one of the least stable countries in the region and caused the flight of capital [29]. On 13 September 2015 «Apache» gunships and fighter jets attacked a group of people in Bahariya oasis of the Western Desert during a lunch stop in the area 350 kilometers away from Cairo. As a result, 8 Mexicans and 4 Egyptians died, because they were mistaken by the pilots for terrorists. The army blamed the tourist company 'Windows of Egypt' for the event, since the later supposedly sent tourists to restricted area without warning. So far 3 families of slain Mexicans agreed to receive a compensation of 140 thousand dollars and not to sue Egypt, but others did not decide what to do [30]. During the same year unknown assailants blowned up Russian Airbus A-321 with 224 passengers and crew members that was flying from the Sinai Peninsula to Saint Petersburg. Later, in March 2016 the flight from Cairo to Alexandria was hijacked to Cyprus. Even before this event 
Egypt received only 6 billion dollars of tourist profits in 2015 [31]. Finally, to add insult to injury, in May 2016 the jet of «Egypt Air» travelling from Paris to Cairo with 66 people onboard crashed while in Egyptian airspace [32]. Such events are extremely rare for generally safe aviation industry even in the least developed countries of Africa and forced international tourists to stay away from Egypt. This means that security of airports is lax or that numerous accomplices of terrorists work here.

In general terrorist attacks in country were highlighted in mass-media to such extend that even considerable devaluation of pound in 2016, which gave euro more purchasing power, did not encourage European tourists to return. In 2016 only 4,9 million foreigners visited Egypt, what can be considered a catastrophic number if to compare with 2015 with 8,1 million tourists and 14,7 million in 2010 [33].

The problem of terrorism, skirmishes in Sinai, and attacks against Copts and their churches forced foreign governments to include Egypt into the list of dangerous countries in respective travel warnings. As a result, many hotels were closed and the rest has to decrease the prices in order to lure international tourists. In 2010 there were 3,8 million workers in hospitality industry and $60 \%$ of them later temporary lost their jobs because of the lack of international tourists. Especially dangerous for Egypt is the loss of Russian and British tourists since the citizens of both countries represented $43 \%$ of foreign visitors [34]. In order to mend situation the government tries to attract Chinese and the citizens of Muslim countries, but complicated relations with the biggest regional powers Saudi Arabia, Turkey and Iran put those efforts into question. On the other hand, the lost of value of Egyptian currency may be considered as incentive for tourists from euro zone to attend Egypt.

The profits of the Suez Canal are also vitally important for the economy. The 163-kilometers long waterway links Europe with Asia by connecting the Mediterranean Sea to the Red Sea. But the problem with it concerned inability of simultaneous movement of the ships in both directions. 17,483 vessels used the Canal in 2015 transporting a total load of 998 million tons [35]. The President Abdel Fattah el-Sisi decided to widen this strategic route in 2014 with a help of 72-kilometers long bypass canal and ordinary Egyptians spent 8,2 billion dollars by buying special non-transferable shares with an attractive interest in order to finance the project. The head of state himself opened a new Canal in 2015 on the board of «El-Mahrousa» - the Presidential yacht that was the first vessel to cross the original Suez Canal in 1869 and remains the oldest active yacht in the world [36]. By executing such grand-scale project of symbolic importance Abdel Fattah el-Sisi wanted to increase his popularity among the population in the wake of rising food prices.

But the timing for extensive works was inappropriate. In 2016 cheap oil prices limited the number of tankers and LNG ships transiting the Canal, since many companies prefer to storage fuel and not to sell it. Some ship crews also chose to cruise around Africa, capitalizing on affordable fuel, in order not to pay exorbitant tolls to Egypt. In 2015 the Canal Authority transferred to budget 5,18 billion dollars, what is understandable if to take into account that the owner of the middle-sized container ship has to pay around 350 thousand dollars for a passage, but the figures for 2016 are only slightly more promising [37].

The lack of dollars forces the Canal Authority to unprecedentedly demand from ship owners the fees with a discount of 3\% for 3 years advanced payment and 5\% - respectively for 5 years advanced payment [38]. Moreover, the huge nationwide scandal with Suez shares continues to rage on. 1,1 million of Egyptians bought investment bonds with $12 \%$ annual interest and paid for them whopping 64 billion Egyptian pounds. But after the sudden depreciation of the national currency in 2016 they already had lost some 5 billion dollars of value of their shares and the government largely ignored their demands for a just compensation [39]. 
During colonial times Egypt and Sudan were famous for cotton fields with the plants of exceptional quality. Today Egypt specialises on production of extra-long cotton, which is well known for its softness and sold to Indian and American markets. However, the events of the «Arab Spring» and following chaos in the economy defined the preoccupation of several Egyptian governments with other developments and many producers took advantage of the situation in order to mix together the cotton seeds of different quality. Egypt also had seven different ministers of agriculture after the removal of the President Hosni Mubarak what ensured a chaos in the industry [40]. As a result, international buyers have lost interest in Egyptian cotton, which became a synonymous with a fake. This causes problems for textile industry that account for $30 \%$ of industrial production in the country and employs 1,2 million people [41]. In 2015 export of textiles brought to Egypt 682 million dollars and garments also contributed another 690 million [42].

There are several other branches of economy as automotive industry, cement, iron and steel, production of aluminium and glass, but they are not contributing to foreign trade in such a crucial way as mentioned ones and mostly oriented towards inner market. However, the business activity inside of Egypt is limited because of low purchasing power of the population.

One of the main drivers of consumption in Egypt is represented by remittances from 8-million strong Diaspora. As a country with an excessive workforce, Egypt traditionally exported blue collar workers to the Gulf. Today their remittances account for 7\% of Egyptian GDP and provide incentive for consumption. Egypt is the leader in the Greater Middle East and tied to the most popular African country Nigeria as the receiver of money transfers with 20 billion dollars a year. Geographically country is divided from the Gulf monarchies with only the Red Sea and Egyptian workers find it easy to work here because of proximity and shared Arabic language. Moreover, this is the sixth most important destination for the remittances worldwide [43]. The banking system of country also remains relatively important in the region since it caters to Africa's third largest economy. 8 Egyptian banks with assets of 205 billion dollars are in the list of 100 most influential financial institutions of the Middle East and in general Egypt occupies $6^{\text {th }}$ place in the regional banking system [44].

The narrow export base coupled with food scarcity and population explosion causes serious economic problems. Hard currency reserves are totally inadequate, if to compare them to population strength. The main threat to the balanced budget of Egypt and stable Egyptian pound is a constant negative balance of foreign trade caused by rising costs of imported food, fuel and medicines and as a result - a deficit of currency needed for purchases of social goods abroad. To illustrate this it is necessary to give the numbers of a severe trade imbalance: Egypt imported goods to the tune of 67 billion dollars in 2015 but its export constituted only 18,5 billion dollars [45].

The government, trying to get hold of dollars, imposes numerous rules for international companies, willing to move profits out of Egypt. Restrictions on transfers of currency from country make it unpopular among investment destinations. European aviation carriers complain that current rules make flights to Egypt highly unprofitable and help to accumulate their debts. As a consequence, the Cabinet of Ministers and Parliament are looking for additional funds everywhere. The deputies are excessively tax tobacco goods and alcoholic drinks, increase the rate of a corporate tax and import tax. In 2016 the President Abdel Fattah el-Sisi ordered to hike import duties by $50-60 \%$ on electronic devices, fridges, soaps, cosmetics, various types of shoes, chocolate and fruits. It was done in order to attract investment in underrepresented fields of economic activity and to encourage local producers to substitute foreign goods, but in reality the prices grew fast and many businesses that borrowed dollars in banks in order to buy goods abroad and resell them with profits are on the verge of bankruptcy [46]. 
Dollars and euro are in a short supply and current forex reserves are unable to support national currency. In order to get 12 billion dollar loan from the IMF the President Sisi ordered Central Bank to float pound in 2016 from 8,8 to dollar to 16 [47]. Today official course of Egyptian currency almost equals the one on the black market what puts to the test the purchasing power of the population. Moreover, the importers of food and medicine incurred considerable losses because of the surge of dollar rate. As a result, the owners of shops are forced to keep prices at extremely high level in order to protect themselves from imminent fluctuations of Egyptian pound.

Probably many Egyptians cherished hopes of positive political changes after the return of army to power. The representative of «Muslim Brotherhood» Mohammed Morsi became the first elected President in the history of country in 2012. However, Abdel Fattah el-Sisi, as the defence minister in the government of Morsi, who was chosen by Morsi as supposedly religious military officer of young age of 57, capitalized on mistakes of Islamists. In July 2013 he organized military takeover of power under the cover of mass protests against the politics of Morsi [48]. Later, in June 2014 he triumphantly won general elections, promising stability and order, and the foremost - improved security after the chaos of the "Arab Spring». Abdel Fattah el-Sisi was portrayed in mass media as a favourite of the GCC monarchies (as former military attaché in Saudi Arabia) that would invest huge amounts in Egypt in order to sustain his rule and counter the threat of political return of «Muslim Brotherhood». In general he was depicted by stateowned news outlets as the savour of the country and the embodiment of strong hand, intended to return her to former glory [49]. It raises the question: For the sake of what Egyptian people organized the «Arab Spring», when instead of aging Hosni Mubarak and his favorite son Gamal as his heir the state power was grabbed by another general without experience?

Despite pledges and promises of stability, after taking over the power he organized systematic repression among the members of «Muslim Brotherhood» and allied Islamist political parties. On 14 August 2013 police and military forces killed at least 817 people in Rabaa Square, where moderate Islamists organized their camp for unlimited sit-in protest [50]. This action was intended to make an intimidating example and to coerce the rest of opposition into submission. According to «Arabic Network for Human Rights Information», there are 60 thousand political prisoners in Egypt out of 105 thousand prison population and 1250 people are missing [51]. The journalists and representatives of NGOs are also under heavy scrutiny, because they are followed and harassed. In 2016 Egypt was the third country in the world only after Turkey and China with some 29 imprisoned journalists and a much bigger number of mass media workers temporary detained [52]. Moreover, even the most popular newspapers with the largest turnout are suffering from lack of the printing paper and necessity to import it on exorbitant prices.

The magnitude of economic problems in Egypt does not allow Abdel Fattah el-Sisi to remain widely popular without painful reforms. In order to avoid them and thus not to lose economic monopoly of the military circles in the short term, the President decided to find several generous donors abroad. Among them - the USA, China and the countries of Gulf Cooperation council, since the members of the EU are not in hurry to assist a new regime.

The strategic tasks of impoverished country are many. First - to stop demographic explosion by any means possible. Second - to win again a trust of foreign tourists in Egypt as in a promising destination. Third - to revive industry and create substitutes for foreign goods, which became prohibitively expensive under the influence of a rising dollar and depreciated Egyptian pound. And finally - to attract foreign direct investment in mining, oil and gas extraction, and agriculture in desert areas, in short in all field of economic activity that are not properly exploited. Egypt with year-round sun radiation also a suitable place for investments in green energy and can follow the path of Northern African leader Morocco in this respect. However, the 
country needs to open up to the process of globalization and this means the threat to the military domination in economic life.

Conclusions. The fall of Hosni Mubarak was caused by the chain reaction in the region after the revolution in Tunisia, the deterioration economy as a result of 2008 world economic crisis, the impunity of police in dealings with ordinary people and perceived corruption of presidential clan. It seemed to outsider that military circles would not be able to come back into political life after tragic events in Tahrir square. However, the violent and chaotic "Arab Spring" created the nostalgia for order and stability among the wide circles of local population on the backdrop of crisis of the main hard currency earner - tourist industry, what Abdel Fattah el-Sisi successfully exploited for his own good and became the head of state, promising to restore order. He supported his authoritarian rule with generous assistance from the Gulf monarchies and later turned for help to the IMF, simultaneously crushing the opposition. As a result, Egyptian society received instead of instability and encroaching Islamic takeover of political liberties by «Muslim Brotherhood» even more unpredictable regime of another Hosni Mubarak but without even minimal political liberties. There are no new elections soon and young people are getting more poor and desperate. All this can lead to popularization of radical opposition and further deterioration of political situation. Overpopulated country simply can not go on like this - with high subsidies and small revenues, limited civil rights and without modernization. To put it simply Egypt needs to change and foreign donors should encourage the leadership of country to take necessary steps towards liberalization.

\section{References}

1. Bovsunivskiy P. (2013). 'Prichini vstanovlennya ta povalennya vladi «Brativ Musulman»u Arabskiy Respublizi Egipet', Zovnishni Spravi, № 10, P. 38-41. Available at: http://uaforeignaffairs.com/ua/ekspertna-dumka/view/article/prichini-vstanovlennja-ta-povalennjapolitichnoji-vladi-b.

2. Vasiliev A., Korotaev A., Isaev L. (2014). 'Voennie vnov u vlasti? Vibori v Egypti', Azia i Afrika segodnya, № 10, P. 2-7.

3. Isael L. (2014). 'Generali ushli, generali vernulis: egipetskoy revoluzii tri goda', Neprikosnovenniy Zapas, № 1. Available at: < http://magazines.russ.ru/nz/2014/1/10i-pr.html>

4. 'Egypt's total population to reach 98 million by next week: CAPMAS' (2015), Ahram, 30 November. Available at: <http://english.ahram.org.eg/NewsContent/1/64/172196/Egypt/Politics-/Egypts-total-population-to-reach--million-by-next-.aspx $>$

5. 'Cairo population 2016' (2016), World Population Review. Com. Available at: <http://worldpopulationreview.com/world-cities/cairo-population>

6. Jason Lemon (2016). 'Egypt's population just increased by 1 million in 6 months', Stepfeed, 25 November. Available at: <http://stepfeed.com/egypt-s-population-just-increased-by-1million-in-6-months-0525;c=stepfeed $>$

7. Will Rasmussen (2008). 'Egypt fights to stem rapid population growth', The New York Times, 2 July. Available at: <http://www.nytimes.com/2008/07/02/world/africa/02iht-egyptecon.4.14179781.html?mcubz=0>

8. Khaled Diab (2014). 'Never mind a new Suez, the Nile Delta needs urgent help', The National, 8 September. Available at: $<$ http://www.thenational.ae/opinion/comment/never-minda-new-suez-the-nile-delta-needs-urgent-help $>$

9. Aswat Masriya (2016). '27.8 percent of Egyptian population lives below poverty line: CAPMAS', Egypt Independent, 27 July. Available at: < http://www.egyptindependent.com/ news/278-percent-egyptian-population-lives-below-poverty-line-capmas> 
10. Asma Alsharif(2016). 'Egypt's unemployment rate eases slightly to 12.7 percent', Reuters, 15 May. Available at: <http://www.reuters.com/article/egypt-unemployment-idUSL5N18C $0 \mathrm{AW}>$

11. Maria Golia (2015). 'Taking on Egypt's bureaucracy', Middle East Institute, 15 October. Available at: http://www.mideasti.org/content/at/taking-egypt $\%$ E2\%80\%99s-big-bureaucracy?page $=1>$

12. Henry Harding (2016). 'ANALYSIS: Egypt's military-economic empire', Middle East Eye, 26 March. Available at: <http://www.middleeasteye.net/news/analysis-egypts-military-economic-empire-35257665>

13. Ahmed Aboulenein, Mostafa Hashem (2016). 'Egypt's Sisi says military accounts for 1.52 percent of economy', Reuters, 24 December. Available at: $<$ http://www.reuters.com/article/us-egypt-economy-military-idUSKBN14D087>

14. Safa Joudeh (2014). 'Egypt military: Protecting its sprawling economic empire', Atlantic Council, 29 January. Available at: $<$ http://www.atlanticcouncil.org/blogs/menasource/egypts-military-protecting-its-sprawling-economic-empire $>$

15. Nader Noureddin (2016). 'Egypt's water concerns', Al-Ahram Weekly, 4 February.

16. Amir Dakkak (2016). 'Egypt's Water Crisis - Recipe for Disaster', EcoMENA, 4 January. Available at: <http://www.ecomena.org/egypt-water>

17. Randa el Bedawy (2014). 'Water resources management: Alarming crisis for Egypt', Journal of Management and Sustainability, Volume 4, Number 3, P. 113, 122.

18. 'Is Ethiopian GERD too big for its location? (2017), Zega.com, 1 January. Available at: $<$ http://www.ezega.com/News/NewsDetails/3758/Is-Ethiopian-GERD-Too-Big-for-Its-Location>

19. Tobias von Lossow, Stephan Roll (2015).'Egypt's Nile water policy under Sisi', SWP comments of German Institute for International and Security Affairs, February, P. 2. Available at: $<$ https://www.swp-berlin.org/fileadmin/contents/products/comments/2015C11_lsw_rll. pdf $>$

20. 'Water hyacinth - Can its aggressive invasion be controlled?'(2013), UNEP Global Environmental Alert Service, April 2013, P. 2. Available at: < https://na.unep.net/geas/getUNEPPageWithArticleIDScript.php?article_id=98>

21. Daniel Pipes (2016). 'Egypt's Water Shortage Could Destabilize the Region', Newmax, 19 February. Available at: <http://www.newsmax.com/DanielPipes/egypt-water-middle-east/ 2016/02/19/id/715152>

22. Neil Ramsden (2016). 'Egypt's soybean imports to grow $181 \%$ as tilapia production soars', Undercurrent News, 23 November. Available at: < https://www.undercurrentnews.com/ 2016/11/23/egypts-soybean-imports-to-grow-181-as-tilapia-production-soars>

23. Hana Afifif (2016). 'Egyptian koshary: The taste of the dollar crisis', Ahram, 21 August. Available at: <http://english.ahram.org.eg/NewsContent/1/151/239355/Egypt/Features/ Egyptian-koshary-The-taste-of-the-dollar-crisis.aspx $>$

24. Ola Noureldin (2017). 'Egypt ranks 108 out of 176 on Transparency International's Corruption Perceptions Index for 2016', Egypt Independent, 7 February. Available at: $<$ http:// www.egyptindependent.com/egypt-ranks-108-out-176-transparency-international-s-corruption-perceptions-index-2016>

25. ' 85 pct of Egyptian women are overweight: 2014 EDHS' (2015), Ahram, 10 May.

26. Hugh Naylor (2014). 'Housing problem must be president's top priority, say Cairo residents', The National, 26 May. Available at: <http://www.thenational.ae/world/middleeast/housing-problem-must-be-presidents-top-priority-say-cairo-residents $>$ 
27. 'Unlocking Africa's tourism potential', Africa Tourism Monitor (2015), October, P. 9.

28. 'Egypt - Closed hotels reopen their doors amid expectations of tourism recovery: investors' (2016), MENA financial network, 17 November. Available at: <http://menafn.com/ 1095058062/Egypt--Closed-hotels-reopen-their-doors-amid-expectations-of-tourism-recovery-investors>

29. Nicolas Parasie (2016). 'Egypt Hopes for Hotel Market Revival', The Wall Street Journal, 3 May. Available at: <http://www.wsj.com/articles/egypt-hopes-for-hotel-market-revival1462287666>

30. 'Investigation into death of 8 Mexican tourists still ongoing: Foreign Ministry' (2016), The Daily News Egypt, 14 May.

31. Menar Khater, Abdel Razek Al-Shuwekhi (2016). 'The hijacked EgyptAir flight: a blow to Egyptian tourism?', The Daily News Egypt, 29 March.

32. Hamza Hendawi (2016). 'Egypt: Traces of explosives found on victims of Paris flight', The Times of Israel, 15 December.

33. 'Tourism to Egypt plummets by 40 per cent in 2016', Middle East Monitor (2017), 5 January. Available at: $<$ https://www.middleeastmonitor.com/20170105-tourism-to-egypt-plummets-by-40-per-cent-in-2016>

34. Abdel Razek Al-Shuwekhi (2016).'Tourism awaiting recovery after a two-year decline', The Daily News Egypt, 8 June.

35. Ahmed Fouad (2016). 'Are ships really avoiding the Suez?, Al Monitor, 29 March. Available at: <http://www.al-monitor.com/pulse/originals/2016/03/egypt-suez-canal-extensiontraffic-plans-concerns.html>

36. Zeinab El-Gundy (2015). 'El-Mahrousa yacht: A history entwined with the Suez Canal', Ahram, 6 August. Available at: http://english.ahram.org.eg/NewsContentP/1/136969/Egypt/ ElMahrousa-yacht-A-history-entwined-with-the-Suez-.aspx>

37. Tamsin Carlisle (2016). 'OPEC deal gives Suez Canal hope for revenue: Fuel for Thought', $S$ and P Global Platts, 5 December. Available at: $<$ http://blogs.platts.com/2016/12/05/opecdeal-gives-suez-canal-hope-revenue>

38. 'Egypt re-works Suez canal toll system' (2016), Hellenic Shipping News, 8 December. Available at: $<$ http://www.hellenicshippingnews.com/egypt-re-works-suez-canal-toll-system $>$

39. Mohammad Ayesh (2016). 'Egypt economic crisis: Four ways currency flotation will cause more problems than it solves', Middle East Eye, 23 November. Available at: <http:// www.middleeasteye.net/columns/four-ways-egypt-s-pound-flotation-will-cause-more-problems-it-solves-2013820354>

40. Deya Abaza (2016). 'Egyptian cotton in peril as exports slide', Ahram, 15 June. Available at: <http://english.ahram.org.eg/NewsContent/3/12/223060/Business/Economy/Egyptiancotton-in-peril-as-exports-slide.aspx $>$

41. Hisham Salah (2016). ' $1 \mathrm{~m}$ sqm provided for development of textile industries in Badr city: Minister of Industry', The Daily News Egypt, 5 December.

42. Patrick Werr (2014). 'Egyptian exporters might need to wait for that boom in sales', The National, 14 December. Available at: <http://www.thenational.ae/business/economy/patrickwerr-egyptian-exporters-might-need-to-wait-for-that-boom-in-sales $>$

43. Shimaa Al-Aees (2016). 'Remittances from UAE to Egypt expected to remain robust', The Daily News Egypt, 16 August.

44. Hossam Mounir (2016). '8 Egyptian banks among top 100 Arab Banks: UAB', The Daily News Egypt, 25 December. 
45. Lin Noueihed, Eric Knecht (2016). 'Egypt industry races to fill void as trade gap to narrow \$11-12 billion in 2016', Reuters, 24 October. Available at: <http://www.reuters.com/article/us-egypt-trade-idUSKCN12O1NR>

46. 'Egypt raises import duties by up to 60 percent to cut deficit' (2016), Middle East Eye, 4 December. Available at: <http://www.middleeasteye.net/news/egypt-raises-tariffs-importedgoods-60-percent-692827788>

47. Mahmoud Kassem (2016). 'Egyptian pound slips further after float', The National, 6 November. Available at: $<$ http://www.thenational.ae/business/economy/egyptian-pound-slipsfurther-after-float>

48. Peter Hessler (2017). 'Egypt's failed revolution', The New Yorker, 2 January. Available at: $<$ http://www.newyorker.com/magazine/2017/01/02/egypts-failed-revolution>

49. 'US navy serenades sweet somethings to Egypt army chief' (2016), Middle East Eye, 14 December. Available at: <http://www.middleeasteye.net/news/video-surfaces-us-navy-serenading-egypt-s-chief-military-staff-1220607609>

50. Stephen Kalin, Maggie Fick (2014). 'Egypt's Sisi wins election, faces economic challenges, Reuters, 29 May. Available at: <http://www.reuters.com/article/us-egypt-election-idUSKB N0E70D720140529>

51. Zvi Bar'el (2016). '60,000 Political Prisoners and 1,250 Missing: Welcome to the New Egypt', Haaretz, 11 September.

52. 'Egypt ranks third in the world for number of journalists imprisoned in 2016: CPJ' (2014), The Daily News Egypt, 14 December. 